\title{
(INDIVIDUAL) RESPONSIBILITY IN DECOLONISING THE UNIVERSITY CURRICULUM
}

\author{
L. Le Grange \\ Department of Curriculum Studies \\ Stellenbosch University \\ Stellenbosch, South Africa \\ e-mail: Ilg@sun.ac.za / https://orcid.org/0000-0002-7096-3609
}

\section{ABSTRACT}

Since the "\#RhodesMustFall" and "\#FeesMustFall" student protests of 2015 and 2016 there has been much written about decolonisation in South Africa, particularly in relation to the curriculum. However, not much has been written about individual responsibility in the process of decolonisation, which Fanon (1967) argued is a necessary condition for decolonisation. In this article I argue that the autobiographical method, currere is one form of decolonisation. I use currere to document my own journey of decolonisation. I conclude that taking individual responsibility in decolonising the university curriculum involves a lifelong affair of unlearning and relearning from which no one is exempt because even those leading the decolonial project take in coloniality on a daily basis. Such a lifelong affair will involve multiple cycles of currere's four steps so that currere, as a form of decolonisation, becomes a spiral of multiple cycles.

Keywords: coloniality, currere, decoloniality, decolonisation, self-liberation, university curriculum

\section{INTRODUCTION}

Decolonisation and decoloniality have received much attention in South Africa following the \#RhodesMustFall and \#FeesMustFall campaigns of 2015 and 2016. Disemelo (2015) saw the two campaigns as co-extensive and concerned with access to equal and quality education, deconstruction of the intricacies of class relations in South Africa, effacing of the microaggressions encountered by black students and exposing the heterosexual, patriarchal, and neoliberal capitalist values that characterise universities in South Africa. During these campaigns, the concerns which Disemelo (2015) highlighted were translated into a call for the university curriculum to be to decolonised. The upshot of this has been a rapid growth in publications by academics in the country on decolonisation. A google scholar search shows that more than 500 publications have been produced on the topic over past five years. Moreover, we have seen the South African state give some attention to decolonisation in relation to the university curriculum. For example, in October 2015 at a Higher Education Summit (HES) arranged by the Ministry of Higher Education and Training, the Minister at the time, Dr Blade 
Nzimande beckoned all universities to Africanise/decolonise. The Council on Higher Education also initiated debate on decolonising of the curriculum through its BrieflySpeaking publication (CHE 2017). I would go as far as to say that we are witnessing the "mainstreaming" of decolonisation in relation to universities, at least in discursive spaces. The purchase that decolonisation has had in terms of disrupting arrangements within universities including dominant approaches to curriculum and pedagogy remains in question. Ndlovu-Gatsheni (in Omanga 2020, 6) argues that this "mainstreaming" of decolonisation may dilute its revolutionary impulse and therefore holds dangers. He writes: "Decolonization has to remain a revolutionary term with theoretical and practical value. If it is immediately embraced by everyone and it's easily on the lips of everyone, there is a danger it might transform into a buzzword and a metaphor."

I am largely in agreement with Ndlovu-Gatsheni (in Omanga 2020) although he does not tell us who may embrace decolonisation, if it is not be embraced by everyone. In particular, I agree with his concern that decolonisation could morph into a buzzword and metaphor such as "transformation" and "Africanisation", and in relation to decolonising the curriculum, metaphors such as "curriculum transformation", "curriculum renewal", etc. For example, Stellenbosch University stated in the media that it has 18 programmes at advanced stages of being decolonised. The Cape Argus article which reported this claim was entitled, Stellenbosch University forges ahead with its decolonisation drive (Mlamla 2020). Such a claim might invite suspicion from those who know the institution, or would take the time to inquire into the institution's history, culture and student and staff demographics. Concerning the latter, 58.1 per cent of the 31765 students enrolled at the university in 2018 were white and seventy-five percent of the university's academic staff is white in a country where the white population is less than 10 per cent (https://www.sun.ac.za/english/Pages/statistical_profile.aspx). The suspicion noted is also supported by empirical studies. A study by Constandius et.al. (2018) documents settler perspectives (from white staff and students) on student protests and decolonising of the curriculum. They found that settler perspectives included ignorance and distance (the notion of "disappear the Native"), fear of regression (e.g. that SA will become like Zimbabwe), racism, exclusion and guilt (what Tuck and Yang 2012, 9 refer to as "settler anxiety"). Moreover, a recent study by Kamanga (2019) documents black students' lived experiences of hidden racism at the university. These studies and knowledge of the history and culture of the university, suggest that its claim that 18 programmes are decolonised may be grossly overstated. In fact, the Mlamla (2020) article and an earlier one published by Etheridge (2018) show that the university is using "curriculum renewal" as a metaphor for decolonisation 
of the curriculum. For a more comprehensive discussion on the Stellenbosch University case, see Le Grange et al. (2020).

In the wake of the Algerian war, Fanon lamented that decolonisation had not taken place, but instead only the Africanisation of colonialism (Pinar 2011). Fanon (1967) came to the conclusion that individual liberation is a necessary condition for decolonisation and therefore that the reconstruction of subjectivity is key to decolonisation. As a matter of fact, Goldie (1999, 79) claimed that for Fanon, true liberation was akin to the accomplishment of subjectivity. So, there is an individual responsibility when it comes to decolonisation and not recognising this is an obstacle to decolonisation. For the subject, decolonisation therefore becomes a lifelong affair of struggle to rid the self from the fetters of coloniality. Maldonado-Torres $(2006,117)$ reminds us that as modern subjects we inhale and exhale coloniality every day and all of time. And Ndlovu-Gatsheni (in Omanga 2020, 6) forcibly reminds us that even leading academic scholars on decolonisation are also products of westernized education and therefore have to engage in self-unlearning.

Furthermore, in discussions on decolonising the university curriculum, the focus necessarily is on the decolonisation part, but this could result in lack of attention to the concept of curriculum, which Le Grange (2016) argues is a carrier of coloniality in the university. Therefore, failure to disrupt dominant approaches to curriculum presents a further impediment to decolonisation. The dominant approaches to curriculum used across the world remain based on a factory model of curriculum and are iterations of Tyler's (1949) rationale.

Against this background I wish to give attention to the challenge of self-liberation that decolonisation presents, through sharing by personal journey of decolonisation using the autobiographical method of curriculum inquiry, which Pinar (1975) called currere, and by so doing attempt to respond to the two obstacles to decolonisation: i) a colonised mind; and ii) its carrier in the university, the curriculum. The rest of the article is structured as follows: Decolonisation and decoloniality; Currere as autobiographical method; My journey of (de)colonisation; and some parting thoughts.

\section{DECOLONISATION AND DECOLONIALITY}

The term decolonisation is variously used in the literature. It refers to insurrections and uprisings against colonisation which eventually resulted in the removal of colonial administrative rule. For example, in Africa the French were confronted with rebellions in Algeria, Tunisa, Morocco, Cameroon and Madagascar (Kelley 2000). Most African countries obtained independence in the mid-twentieth century. In the wake of (or parallel to) insurrections and resistance movements we saw what might be termed intellectual or cognitive 
decolonisation evident in what Kelley (2000) refers to as a "tidal wave"2 of anticolonial literature produced in the post-war period.

Decolonisation continues to be used by indigenous scholars to refer to processes of: discovering and recovering their own histories, cultures and identities; mourning their loss of their knowledges, cultures and languages; correcting the deficit ways in which colonised peoples have been defined and theorised; invoking their histories, indigenous knowledges and worldviews to imagine alternative futures; seeking self-determination; internationalising the common experiences, struggles and hopes of colonised people; protecting the knowledges of colonised peoples; and so forth (for more detail, see Smith 1999; Chilisa 2012).

However, the distinction between decolonisation and decoloniality made by Latin American scholars have been helpful in understanding the legacy of colonialism which imbues the "postcolonial world" and neoliberal order, and why decoloniality is so necessary. Quijano (2007) gave new meaning to the legacy of colonialism. For Quijano's (2007) the legacy of colonialism is the colonial matrix of power that has four interconnected spheres: control of economy; control of authority; control of gender and sexuality and control of subjectivity and knowledge. Grosfoguel (2007) argues that the removal of colonial administrations produced the myth of a postcolonial world because what we have witnessed was a shift from a period of global colonialism to a period of global coloniality. In a similar vein, Maldonado-Torres (2007, 243) points out that coloniality refers to "long-standing patterns of power that ... define culture, labour, intersubjectivity relations, and knowledge production well beyond the strict limits of colonial administrations". Moreover, Mignolo (2011) argues that coloniality is the darker side of modernity. In other words, there is no European modernity without coloniality. The darker side of modernity, is the slave trade, imperialisms, violent genocides, racism, sexism, all forms of oppressions suffered by colonised peoples and the current neoliberal order. Some of the "crimes" of the darker side of modernity are: the murdering and displacement of pre-existing knowledges (epistemicide); the killing and displacement of the languages of colonised peoples (linguicide); and the killing and displacement of peoples' cultures (culturecide) (NdlovuGatsheni in Omanga 2020). Drawing on the work of these Latin American scholars NdlovuGatsheni (2013b) argues that coloniality has three interlocking concepts: coloniality of power; coloniality of knowledge; and coloniality of being. Coloniality of power relates to the current asymmetrical global power structure that is a consequence of modernisation, which has brought benefits to the West through imposing the slave trade, imperialism, colonialism and apartheid on the rest. Coloniality of knowledge relates to how the genesis of disciplines in the West resulted in epistemicides in the Global South and how Africa is now burdened with knowledge 
that is disempowering. Coloniality of being relates to how whiteness increased its ontological density to the extent that it now far exceeds that of blackness and how Descartes's "I think, therefore, I am" morphed into "I conquer, therefore, I am" (Ndlovu-Gatsheni 2013a, 12).

Decoloniality is an analytic of coloniality. It relates to a critical consciousness of the logic of coloniality, resists expressions of coloniality and takes actions to transcend coloniality (Le Grange 2020). In other words, decoloniality is more than the removal of colonial governance and entails the decolonisation of the interlocking domains of knowledge, power and being. The context of the discussion on decolonisation and decoloniality in this article is the curriculum therefore I next turn to a discussion on curriculum and outline an alternative approach to those configured in the Tylerian ${ }^{3}$ mould, the autobiographical method currere.

\section{CURRERE AS AUTOBIOGRAPHICAL METHOD}

Currere was developed as a method in the USA in the wake of Joseph Schwab's $(1969,1)$ pronouncement that "the field of curriculum is moribund". He argued for practical ways of solving problems of education through deliberation rather than simply applying theories. The concept of currere was first presented by William Pinar (1975) at the annual conference of the American Education Research Association (AERA) held in Washington, DC. The method that Pinar proposed combined insights from existentialism and the psychoanalytic technique of free association to build a multidimensional biography based on conceptual and pre-conceptual experiences.

Currere is the Latin root of "curriculum", which means "to run". It privileges the individual, and, Pinar $(2011,2)$ avers that it is a complicated concept that we have with self because each of us is different. Each of our conversations with self will necessarily be different from that of anyone else's. The invocation of currere shifts the angle of vision away from the concept of a predetermined course to run (the Grecian "chariot track"), to focusing on how each individual runs their own course, given that each one is unique in relation to their make-up, context, hopes, aspirations and interactions with other humans and non-human nature. Put differently, each individual has her own life story, which she comes to understand through academic study. Currere, disrupts dominant approaches to curriculum (studies) that focus on curriculum development based on Tyler's (1949) rationale. Tyler $(1949,1)$ argued that the curriculum development process incorporates the following four elements: the educational goals the institution will seek to attain; the educational encounters that will be provided to achieve these goals; the effective organisation of educational experiences to ensure attainment of the stated goals; and how the attainment of the goals will be ascertained. 
Pinar develops currere as an autobiographical method with four steps or moments that signify both temporal and reflective moments for autobiographical research of educational experiences (Pinar et al. 1995):

- $\quad$ The regressive step entails focusing on the past to enlarge and transform one's memory. This would involve remembering all influences on one's life in the past be they environmental, cultural, religious, educational, political, etc. and how these impact on one's present.

- The progressive step involves focusing on the future. Here the subject envisions that which is not yet present; one meditatively imagines possible futures and also how the future inhabits the present (Pinar 2004, 36). This step might focus on personal aspirations but also future possibilities.

- The analytical step involves bracketing the self from the past and future to create a space of freedom in which one analyses how past and present are imbricated in one another (Pinar 2004, 36-37).

- The synthetical step entails re-entering the lived present and where one asks what the meaning of this present is.

The reason for discussing Pinar's autobiographical method currere is because it resonates strongly with the project of decolonisation in that the (re)construction of the subject is central to both. Pinar (2011) invokes Fanon (1967), referred to earlier, and argues that subjective reconstruction, which is at the heart of currere, is one form of decolonisation. As Pinar (2011, 40) writes: "(T)he regressive-progressive-analytic-synthetic method of currere - can be political when it disables, through remembrance and reconstruction, colonisation through interpellation".

However, autobiography holds the risk of sentimental solipsism. Pinar (2011) recognises the danger of the narcissism of identity politics and therefore proposes that currere should serve as an impetus for political mobilisation. Le Grange (2021) outlines how this could be realised using currere's four stages. Firstly, the regressive step enables the individual to focus on how he/she has actively taken up (de)colonial discourses in their life. It entails a moment in selfcriticism and depicts the beginning of the individual's efforts to rid the self from the shackles of coloniality. Secondly, in the progressive step the individual imagines a future that is more just, more democratic, more sustainable, authentically postcolonial (decolonised), for example. Thirdly, in the analytical step, the individual detaches him/herself from the past and future and 
analyses how the past, future and the present are imbricated in one another. By distancing himself/herself from the past and future the individual is able to experience a moment of freedom from the present - liberated from thoughts that are colonising. Fourthly, in the synthetical step the individual re-enters the present with a renewed sense of self, able to see the wholeness of past, present and future, and asks what does this mean and what can I do? This is the moment where the individual can join others in collective action to transform the present so as to make possible a different future. The idea of currere as a form of decolonisation has resonance with Ndlovu-Gatsheni's (in Omanga 2020) contention that decolonisation requires self-unlearning, which involves unlearning in order to relearn. Given that the process of unlearning and relearning is a lifelong process, I suggest that Pinar's four steps of currere might represent one cycle of inquiry and that in the lifelong process of unlearning and relearning the subject undergoes several cycles of inquiry resulting in a spiral of ongoing cycles of inquiry, as is the case with action research.

\section{MY JOURNEY OF (DE)COLONISATION}

\section{Regressive step}

I was born in Cape Town in 1963, and classified "coloured" according to the Population Registration Act (Act No. 30 1950), which was promulgated by the then National Party government to give effect to its ideology of apartheid. Although many South Africans who were classified "coloured" during apartheid (and their descendants) identify themselves as coloured 4 in post-apartheid South Africa, I have never embraced this imposed term for reasons that will be made evident later. However, because of the Group Areas Act (GAA) I grew up in "coloured" communities, attended schools designated for "coloured" children and did my first degree at a university designated for "coloured" students. As a consequence, I had relatively little contact with "white" South Africans and even less contact with "Africans" and "Indians". Although I had relatively little social contact with "white” South Africans, I like many black South Africans became a consumer of white culture and developed whitely thinking. Growing up "coloured" during apartheid meant that your home language was either Afrikaans or English. My home language was English and I learned Afrikaans because it was spoken by many people that I interacted with and Afrikaans second language was a compulsory subject for those doing their schooling in English. Given that language and culture are intertwined, as I learned English as a home language I was also socialised into Western culture. I was interpellated into European ${ }^{5}$ culture in the earlier stages of my life through multiple means: the works of the 
British authors and poets that my father read at the dinner table, the Eurocentric school organisation and curriculum; the media (first radio and later television); attending a church that was predominantly white; and so forth.

Although the church I grew up in embraced some democratic principles (such as the priesthood of all believers) it was politically conservative so did not engage in political activities - its position was that the role of the church was to pray for the government. Although I have discarded some Christian beliefs of my childhood, the influence of the concept love, which is central to the Christian faith is probably why I remain a pacifist to the core. The year 1976 was a watershed moment for me and the beginning of my political consciousness. I was in Standard 5 (Grade 7) and recall that we were dismissed early from school on a particular day because the two local high schools were going to join schools from other areas in a protest march to the central business district of Cape Town. The march did not proceed very far because students met with police violence. This was when I first became aware of police brutality and the establishment of what was called riot squads. There were broader protests happening in the community at the time, and I recall some community members advising us that if one were confronted by protesters you should raise your fist and shout, "black power, black power ....". I was to later understand that the events occurring in my community were protests against apartheid education that began in Soweto and, although it morphed into nation-wide protests, this moment in South Africa's history has become known as the Soweto Uprisings of 1976. The reference to "black power" related to the rise of Black Consciousness in the earlier 1970s, with its key protagonist being Steve Bantu Biko.

The school boycotts of 1980 were especially important to me and furthered my political consciousness. In 1980 I was in Standard 9 (Grade 11), during the period of prolonged school boycotts. These began in the city of Cape Town and quickly spread throughout the country (Christie 1985, 244). Students boycotted "normal school activities", demanding a single national education department and for educational resources to be allocated equitably to all children. During the boycott period I attended awareness programmes arranged by the student representative council (SRC) at my school. In these programmes I learned a great deal, such as valuing non-racism, why I should not participate in multi-racial sport, and so forth. Learning about non-racism made me reject the imposed notion of "coloured". I also learned that through exercising their agency students could change some of the conditions of teaching and learning. Even though schools continued to be segregated after the 1976 uprisings and 1980 boycotts, the Apartheid State provided more teaching resources to schools, fixed school buildings and established the De Lange Commission (De Lange 1981) to investigate education in South Africa (Christie 1985, 248). It was at this juncture that I came to view education as a site of 
struggle and became aware of how human agency could effect change. Although my awareness about the ills of apartheid had increased, I do not remember making meaningful links between apartheid policies and state pedagogy at the time. But this period marked the beginning of my decolonisation.

I did my Bachelor of Science (BSc) studies in the 1980s at what was then perceived to be one of the most radical universities in South Africa, the University of the Western Cape (UWC). My studies at UWC were often "disrupted" by student political activities such as public demonstrations, lecture boycotts and mass gatherings. My political consciousness developed further during this period and so too my ecological consciousness as a consequence of my formal studies in biological and earth sciences. However, I did not develop meaningful connections between them. In fact, there was a dissonance between the protests we engaged in as students, the freedom songs we sung, the political speeches we listened to during mass meetings and what happened in lecture venues. After sporadic periods of class boycotts we would return to lecture venues and be taught subject matter decided by mainly white Afrikaner lecturers. Other than the grassroots Peoples' Education movement of the 1980s, which engaged in developing community-based alternative curricula (Levin 1991), our protests did not focus much on matters curriculum - dismantling legal apartheid was the priority. I don't recall questioning the science that I was taught and in fact loved what I was learning. It was when I read Haraway (2000) years later that I realised that it was science as an interpretive framework that I had found so appealing. Through the political education I received during my studies at UWC, in the wake of the death of Steve Biko and rise of the United Democratic Front (UDF), I embraced blackness and viewed myself as black in the Black Consciousness sense of the word.

After completing my BSc degree, I enrolled for a Higher Diploma in Education (HDE) at the University of Cape Town. One HDE course was named Theory and Philosophy of Education. The course focused on contesting ideologies in South Africa and how these philosophies influenced education. The course placed emphasis on Afrikaner Nationalism, Liberalism and Social Reconstructionism. The course was meaningful in several ways: it facilitated my understanding of how sets of ideas infuse meaning into peoples' lives as well as social practices such as education; it assisted me to begin to appreciate the ambiguities in my own life as a consequence of my socialisation in a deeply divided South Africa; what I learned served as an initial basis for me to later develop philosophical goggles not only to understand but also to critique manifestations of these ideologies in social practices such as educational research, curriculum and pedagogy. But, this course in which different philosophical perspectives were presented was also emblematic of the liberation education I received at UCT through not only my HDE studies, but Bachelor of Arts (BA), Bachelor of Education (BEd) 
and Master of Education (MEd) qualifications I completed at the institution. It was during my studies at UCT that began to read critical theories, including various authors writing on critical pedagogy such as Paulo Freire (1972), Giroux (1979), Apple (1979), etc.

After qualifying as a high school teacher, I taught biology and general science in a state school for a decade. The school I taught at was administered by an education department designated for "coloureds" called the Administration: House of Representatives. In the period that I was a school teacher South Africa's largest teachers' union was established, the South African Democratic Teachers Union (SADTU). I did not join the union because I disagreed with its approach to hold protest marches during school hours (there were many at the time) to the detriment of the education of children. However, I joined the union in its protests on the days that schools were closed and on the rare protests that occurred on Saturdays. I joined the African National Congress (ANC) in the early 1990s and actively campaigned to mobilise support for the organisation leading up to the 1994 democratic election $^{6}$. It was odd that I was member of the ANC and not a member of SADTU, and my choices at the time might be ascribed to liberal values that I had tacitly acquired through the liberal education that I had received.

Through the teacher networks I was involved with/in, I became a member of the Environmental Education Association of South Africa (EEASA). The Western Cape branch of the organisation had to host the annual conference of the organisation and it was to take place at Stellenbosch University. It was in the planning phase of this conference that I met an Afrikaner academic from Stellenbosch University who had accepted responsibility for his contribution to apartheid; he openly shared that he had been a member of Afrikaner Broederbond $^{7}$, had been a police reservist during apartheid, declared that the church had lied to him, his parents had lied to him, etc. So when he invited a colleague and I to come and teach part-time at the university it was because of who he was (or had become) and a gut feeling that it was the right thing to do, that made me accept the invitation. In 1996 I commenced part-time teaching in the Faculty of Education at the University of Stellenbosch. I left full-time school teaching at the end of 1996 to pursue Doctor of Philosophy $(\mathrm{PhD})$ studies. I continued to lecture part-time at the university until I was appointed to a full-time academic position in 1999. Stellenbosch University is a historically white and Afrikaans university, but at the time of my appointment (two years into South Africa's democracy) its monocultural identity was being challenged.

My employment at Stellenbosch University has brought personal benefits - my academic career has in part advanced because of the research culture at the university and the infrastructural support that a historically advantaged university makes available. However, even 
though the staff and student demographics has slowly changed since 1994 and the language of learning and teaching (LOLT) now is mostly English, the institutional culture remains unchanged. The molar identity of the university is White, male, Afrikaans, Christian, heterosexual and able-bodied. I have observed how minority black (my understanding of black) students sit clustered and segregated from white students in undergraduate lecture venues. The findings of the research of Constandius et al. (2018) and Kamanga (2019) are therefore unsurprising. Constandius et al. (2018) found that white staff and students who participated in their study display several settler perspectives, which included ignorance, fear of regression (that South Africa will become Zimbabwe), racism, exclusion and guilt. The Kamanga (2019) study revealed hidden racism at the university experienced by black students. My stay and Stellenbosch University has been one of struggle and tension - personal career advancement versus the need to contribute to changing the culture of the university.

My involvement in environmental education and the investigation into the underlying causes of the global environmental crises resulted in me questioning the dominance of Modern Western Science (MWS) and how this dominance could be challenged by the inclusion of indigenous knowledges (for example see Le Grange 2000; Le Grange 2004a; Le Grange 2007a; Le Grange and Aikenhead 2017). Over time I also began reading a range of philosophies, mainly critical theory and French poststructuralism, in particular the works of the philosopher Gilles Deleuze and those he produced in collaboration with psychoanalyst Felix Guattari (for examples see Le Grange 2005; Le Grange 2007b; Le Grange 2011). More recently, I have begun reading a range posthuman theorists. However, I have also engaged with African philosophies (in particular with ubuntu) as well as the works of African philosophers such Kwasi Wiredu, Paulin Hountondjii and Magobe Ramose (see Le Grange 2004b; Le Grange 2012a; Le Grange 2012b). I have also theoretically explored resonances and dissonances between African philosophies and Western posthuman philosophies (see Le Grange 2018). My scholarly work represents a growing engagement with African and indigenous philosophies, but also a reluctance to fully abandon Western philosophies - I admit that this is a reluctance that continues. Since the student protests of 2015 and 2016, I have engaged more directly with the theme of decolonising the university curriculum.

In my teaching, although I have infused content on indigenous knowledges and decolonisation, I continue to draw chiefly from knowledge of the Western canon and although I have experimented with alternative pedagogies such as introducing African talking circles, my pedagogies are mainly western-based. In short, my journey of decolonisation goes back long before the student protests of 2015 and 2016, but it is a journey filled with contradictions, reflecting a need for ongoing unlearning and relearning. 


\section{Progressive step}

The progressive step is an opportunity to dream, to imagine a different future. I dream of a decolonial South Africa where the colonial matrix of power has been disrupted to the extent that the wealth of the country is shared more equally, where all the country's people have access to land and enjoy sustainable livelihoods, where all forms of discrimination have been eradicated not merely legally but in practice, where all knowledges are placed on an immanent plane so that these can be equitably compared. In fact, much of what I dream for South Africa is captured in, The Freedom Charter that was embraced at Kliptown in 1955 (https://www.marxists.org/subject/africa/anc/1955/freedom-charter.htm). To put all of this in simple terms, I dream that all South Africans will be able to live dignified lives. Moreover, I dream that an ethic of care will imbue South African society, but not only focused on humans but extended to all of life. I dream that Stellenbosch University will become an African university instead of a university in Africa as it now is. From the insights gained from the literature reviewed earlier, I know that this requires more than changing the demographics of the institution. Importantly, it requires changing the culture of the institution to one that is attuned to the heartbeat of Africa ${ }^{8}$, and reflects the rich diversity of the knowledges and lived experiences of (South) Africans. I dream that the pedagogical encounters I have with students will nurture unique becomings that will have transformative effects in the world.

\section{Analytical step}

When Deleuze and Guattari (1994) invoked the notion "a people-yet-to-come", they did not refer to "a people of the future" but "a people-here-and-now". In other words, "the people-yetto-come" refers to the people presently living who are in the process of becoming. An imagined future is therefore always immanently present and the potential for its becoming exists prior to thought. A decolonised future therefore depends on what I do individually and what we do collectively. There may appear to be a gap between the present and an imagined future, but the very act of imagining a different future signifies that it is already in-becoming. So, it is up to me to invigorate vectors of escape from that which is colonising and through a process of decolonising of the self, the basis could be laid for collective (political) mobilisation. I should begin by acknowledging the contradictions (highlighted in my regressive narrative) in my thoughts and actions and be consciously aware that my efforts at decolonising always run the risk of becoming colonising. My research, teaching and writing should therefore be a reflexive process that incorporates both personal and epistemic/disciplinary reflexivity. Personal 
reflexivity involves being conscious of positionality, aware of the privileges I enjoy as university professor because of the cultural and social capital that I have been able to accumulate and how this plays out in my actions and also how my cartography ${ }^{9}$ (described in the regressive step) informs my knowing, being and actions. This relates to the coloniality of being. Epistemic/disciplinary reflexivity relates to critically understanding the role that Western disciplines have played in coloniality, so in this instance it would be necessary for me not to burden students with irrelevant and colonising knowledge and also not to produce such knowledge through my research.

\section{Synthetical step}

This step brings one back to the reality of the present and is invoked so that one is not stuck in the past and does not live in a fantasy world. Contemporary society is faced with multiple and complex problems: there is growing inequality in the world, environmental problems have reached unprecedented levels, technology is advancing at a rapid rate (producing both benefits and threats) and new pandemics such COVID-19 are wreaking havoc on the planet. These global challenges are evident in South Africa, which is a miniature of the world. Moreover, these challenges are interlinked and largely manifestations of an entrenched global colonial matrix of power. Capitalist exploitation of the land and pollution by industries is responsible for a great deal of environmental destruction. Neoliberal capitalist agricultural practices are also responsible for the emergence of more virulent viruses such as the one causing the COVID-19 pandemic (McKinley 2020). Control over subjectivity and sexuality has seen people of colour and women bear the brunt of political, social and economic oppression and advances in technology have given rise to a digital divide.

Furthermore, the contemporary university has morphed into a neoliberal one, characterised by creeping managerialism, accountability and performative regimes. We have seen the publication enterprise morph into a global science network, where the production of knowledge is no longer regulated by scholars/universities but by private entities and governments. With respect to teaching, we have witnessed western pedagogies becoming disseminated faster through pre-packaged learning materials and this could be exacerbated with the pivot towards online teaching. In all of these developments I am a victim and perpetrator. Therefore, individual and collective decolonisation is not an easy task and so the road to the future that I imagined in the progressive step is necessarily one of struggle with self and against the colonising effects of a neoliberal order. But it is a challenge that I must confront, because without a decolonised world there is no future for the planet - we will have no home. So I must 
keep working on the self and engage in complicated conversation with my colleagues students, and the earth because it will necessitate listening to others for the purpose of self-unlearning. But, more importantly, my journey does not have a personal end. Rather, it is a means to collective mobilisation within South Africa and in transnational spaces that globalisation affords.

There is a sense of wholeness that I am experiencing at this point as my intellectual pursuits in the domains of environmental education, curriculum studies, indigenous knowledge, decolonisation and (post)humanism intersect in the (post)Anthropocene, and expressed in my articulation of the concept Ubuntu-currere (see Le Grange 2016; Le Grange 2018). Ubuntucurrere is informed by the African value of ubuntu which signifies relatedness between humans. This relatedness between humans is emblematic of relatedness of everything in the cosmos, which is expressed in the Shona concept of ukama. Given that currere is concerned with the becoming of the subject, combining ubuntu and currere, emphasises that subjectivity is ecological, that the becoming of the human occurs in relationship with other human beings and the more/other-than-human world. Responsibility in troubled times means caring for others (both human and more/other-than-human).

\section{SOME PARTING THOUGHTS}

My effort in this article marks a first attempt to document my journey of decolonisation. Fanon (1967) reminded us that decolonisation is dependent on individual liberation, so none of us is exempted from this process. Currere provides one form of decolonisation and presents not only a way of decolonising the self, but also disrupts dominant approaches to curriculum configured in the Tylerian mould. Individual liberation, however, occurs in intra-action with other humans and the more/other-than human world - the self is embedded in society and the cosmos.

It would be inappropriate for me to conclude by putting what I have said in nutshell for the reader. My journey is an ongoing one, and necessitates further exploration on my part. There has not been sufficient space to give equal attention to all the currere steps in this article, and so what has been captured should be viewed as a moment is a lifelong affair of unlearning and relearning.

\section{ACKNOWLEDGEMENT}

This research was funded by the National Research Foundation (SA) with grant number 119518. 


\section{NOTES}

1. Tuck and Yang $(2012,9)$ argue that this is a method used by settlers to avoid dealing with the process of authentic decolonisation. Constandius et. al. (2018) aver that this notion was evident when white students would ask why black students would not go to "other" universities.

2. Kelley $(2000,8)$ borrows "tidal wave" from Malcolm $X$ who described the post-war period as "tidal wave of color".

3. Tylerian has reference to American curriculum scholar Ralph Tyler.

4. For detailed discussions on the complexities of coloured identities in post-apartheid South Africa, see Hendricks (2005), Adhikari (2005) Isaacs-Martin and Petrus (2012).

5. My usage here includes both Britain and Continental Europe.

6. I disengaged with party politics when I became an academic.

7. The Afrikaner Broederbond was a secret organisation that promoted Afrikaner interests. It was established in 1918.

8. In his book, The Heartbeat of Indigenous Africa, Mosha (2000) argues for the unrelenting quest to educate the whole person: body, mind and spirit.

9. I prefer to use cartography than biography because it adds a spatial dimension.

\section{REFERENCES}

Adhikari, M. 2005. Not white enough, not black enough: Racial identity in the South African coloured community. Athens: Ohio University Press.

Apple, M. W. 1979. Ideology and curriculum. London: Routledge and Paul.

Constandius, E., O. Nell, N. Alexander, M. Mckay, M. Blackie, R. Malgas, and E. Setati. 2018. "\#FeesMustFall and decolonizing the curriculum: Stellenbosch University students' and lecturers' reactions." South African Journal of Higher Education 32(2): 65-85.

CHE see Council on Higher Education.

Chilisa, B. 2012. Indigenous research methodologies. Los Angeles, CA: Sage.

Council on Higher Education. 2017. "Decolonising the curriculum: Stimulating the debate." BrieflySpeaking Number 3(November 2017).

Christie, P. 1985. The right to learn: The struggle for education in South Africa. Braamfontein: Ravan Press.

Deleuze, G., and F. Guattari. 1994. What is philosophy? Translated by Hugh Tomlison and Graham Burchell. New York: Columbia University Press.

De Lange, J. 1981. The provision of education in South Africa (the De Lange Report). Pretoria: HSRC.

Disemelo, K. 2015. "Student protests are about much more than just \#FeesMustFall." Mail\&Guardian. http://mg.co.za/author/katlego-disemelo (Accessed 28 April 2016).

Etheridge, J. 2018. Decolonising education: How one SA university is getting it done. News 24 . https://www.news24.com/news24/analysis/decolonising-education-how-one-sa-university-isgetting-it-done-20180507 (Accessed 10 June 2020).

Fanon, F. 1967. Towards the African revolution. Translated by H. Chevalier. New York, NY: Grove Press.

Freire, P. 1972. Pedagogy of the oppressed London: Penguin.

Giroux, H. 1979. "Schooling and the culture of positivism: Notes on the death of history." Educational Theory 29(4): 263-284.

Goldie, T. 1999. "Saint Fanon and homosexual territory." In Frantz Fanon: Critical perspectives, ed. A. C. Alessandrini. London, UK: Routledge. 
Grosfoguel, R. 2007. “The epistemic decolonial turn.” Cultural Studies 21(2-3): 211-223.

Haraway, D. J. 2000. How like a leaf: An interview with Thyrza Nichols Goodeve. New York: Routledge.

Hendricks, C. 2005. "Debating coloured identity in the Western Cape." African Security Studies 14(4): $117-119$.

Isaacs-Martin, W., and T. Petrus. 2012. "The multiple meaning of coloured identity in South Africa." Africa Insight 42(1): 87-102.

Kamanga, E. 2019. Lived experiences of hidden racism of students of colour at a historically white university. Master of Arts in Psychology dissertation. Stellenbosch: Stellenbosch University.

Kelley, R. D. G. 2000. A poetics of anticolonialism. New York: Monthly Review Press.

Le Grange, L. 2000. "Is there a 'space' for enabling disparate knowledge traditions to work together? Challenges for science (education) in an African context." South African Journal of Education 20(2): 114-117.

Le Grange, L. 2004a. "“Multicultural' science in South Africa's National Curriculum Statement." Africa Education Review 1(2): 204-219.

Le Grange, L. 2004b. "(South) African(a) philosophy of education: A reply to Higgs and Parker." Journal of Education 34: 143-154.

Le Grange, L. 2005. "Guattari's philosophy of education and its implications for environmental education in (post)colonial Africa." Southern African Journal of Environmental Education 22: $33-45$.

Le Grange, L. 2007a. "Integrating western and indigenous knowledge systems: The basis for effective science education in South Africa?" International Review of Education 53(5-6): 577-591.

Le Grange, L. 2007b. "The 'theoretical' foundations of community service-learning: Fom taproots to rhizomes." Education as Change 11(3): 3-13.

Le Grange, L. 2011. "Sustainability and higher education: From arborescent to rhizomatic thinking." Educational Philosophy and Theory 43(7): 742-754.

Le Grange, L. 2012a. "Ubuntu, ukama, environment and moral education." Journal of Moral Education 41(3): 329-340.

Le Grange, L. 2012b. "Ubuntu, ukama and the healing of nature, self and society." Educational Philosophy and Theory 44(S2): 56-67.

Le Grange, L. 2016. "Decolonising the university curriculum." South African Journal of Higher Education 30(2): 1-12.

Le Grange, L. 2018. "The notion of Ubuntu and the (post)humanist condition." In Indigenous philosophies of education around the world, ed. J. Petrovic and R. Mitchell. New York: Routledge.

Le Grange, L. 2020. "The (post)human condition and decoloniality: Rethinking and doing curriculum." Alternation 31: 119-142.

Le Grange, L. 2021. "Decolonising the university curriculum: The what, why and how." In Transnational education and curriculum studies: International perspectives, ed. L. J. Chi-Kim and N. Gough. New York: Routledge.

Le Grange, L., and G. Aikenhead. 2017. "Rethinking the 'Western Tradition': A response to Enslin and Horsthemke." Educational Philosophy and Theory 49(1): 31-37.

Le Grange, L., P. Du Preez, L. Ramrathan, and S. Blignaut. 2020. "Decolonising the university curriculum or decolonial-washing? A multiple case study." Journal of Education 80: 25-48.

Levin, R. 1991. "People's education and the struggle for democracy in South Africa." In Apartheid education and popular struggles, ed. E. Unterhalter, H. Wolpe, T. Botha, S. Badat, T. Dlamini, and B. Khotseng, 117-130. Johannesburg: Ravan Press.

Maldonado-Torres, N. 2006. "Cesaire's gift and the decolonial turn." Radical Philosophy Review 9(2): $111-138$. 
Maldonado-Torres, N. 2007. On coloniality of being: Contributions to the development of a concept. Cultural Studies 21(2-3): 240-270.

McKinley, D. 2020. Coronavirus and capitalism: Structural foundations and opportunities for systemic change. Daily Maverick. https://www.dailymaverick.co.za/opinionista/2020-03-24trashed-2/ (Accessed 5 June 2020).

Mignolo, W. D. 2011. The darker side of western modernity: Global futures, decolonial options. Durrham \& London: Duke University Press.

Mlamla, S. 2020. Stellenbosch University forges ahead with its decolonisation drive. https://www.iol. co.za/capeargus/news/stellenbosch-university-forges-ahead-with-its-decolonisation-drive43055870 (Accessed on 26 June 2020).

Mosha, R. S. 2000. The heartbeat of indigenous Africa: A study of the Chagga education system. New York: Routledge

Ndlovu-Gatsheni, S. J. 2013a. Empire, global coloniality and African subjectivity. New York: Berghagn Books.

Ndlovu-Gatsheni, S. J. 2013b. "Why decoloniality in the 21st century?" The Thinker 48: 10-15.

Omanga, D. 2020. Decolonization, decoloniality, and the future of African Studies: A conversation with Dr. Sabelo Ndlovu-Gatsheni. https://items.ssrc.org/from-our-programs/decolonizationdecoloniality-and-the-future-of-african-studies-a-conversation-with-dr-sabelo-ndlovu-gatsheni/ (Accessed 10 June 2020).

Pinar, W. F. 1975. The method of currere. Paper presented at the annual meeting of the American Educational Research Association. Washington, D.C.

Pinar, W. F. 2004. What is curriculum theory? Mahwah, NJ: Lawrence Erlbaum Associates.

Pinar, W. F. 2011 The character of curriculum studies: Bildung, currere and the recurring question of the subject. New York, NY: Palgrave Macmillan.

Pinar, W. F., W. M. Reynolds, P. Slattery, and P. M Taubman. 1995. Understanding curriculum: An introduction to the study of historical and contemporary curriculum discourses. New York: Peter Lang.

Quijano, A. 2007. "Coloniality and modernity/rationality." Cultural Studies 21(2-3): 168-178.

Schwab, J. J. 1969. “The practical: A language for curriculum.” The School Review 78(1): 1-23.

Smith, L. T. 1999. Decolonising methodologies: Research and indigenous peoples. London, UK: Zed Books.

Tuck, E., and K. W. Yang. 2012. "Decolonization is not a metaphor." Decolonization: Indigeneity, Education and Society 1(1): 1-40.

Tyler, R. W. 1949. Basic principles of curriculum and instruction. Chicago: University of Chicago Press. 